\title{
In Vitro Analysis of the Combinatory Effects of Novel Aminonaphthoquinone Derivatives and Curcumin on Breast Cancer Progression
}

\author{
MELANIE C. PEREIRA ${ }^{1,2}$, RAUSHAAN MOHAMMED ${ }^{3}$, WILLEM A.L. VAN OTTERLO ${ }^{3,4}$, \\ CHARLES B. DE KONING ${ }^{3}$ and HAJIERAH DAVIDS ${ }^{2}$ \\ ${ }^{1}$ Department of Biochemistry and Microbiology, Nelson Mandela University, Port Elizabeth, South Africa; \\ ${ }^{2}$ Department of Physiology, Nelson Mandela University, Port Elizabeth, South Africa; \\ ${ }^{3}$ Molecular Sciences Institute, School of Chemistry, University of the Witwatersrand, Johannesburg, South Africa; \\ ${ }^{4}$ Department of Chemistry and Polymer Sciences, Stellenbosch University, Western Cape, South Africa
}

\begin{abstract}
Background/Aim: We previously reported the potential of aminonaphthoquinone derivatives as therapeutic agents against breast and other oestrogen-responsive tumours when combined with curcumin. This study aimed at screening of novel aminonaphthoquinone derivatives (Rau 008, Rau 010, Rau 015 and Rau 018) combined with curcumin for cytotoxic, anti-angiogenic and anti-metastatic effects on MCF-7 and MDA-MB-231 breast cancer cells. Materials and Methods: Cytotoxic and anti-angiogenic effects were analysed using the 3-(4,5-dimethylthiazol-2-yl)2,5-diphenyltetrazolium bromide assay and enzyme-linked immunosorbent assay; while anti-metastatic effects were measured using adhesion assay, Boyden chambers and Matrigel. Results: Curcumin combined with Rau 008 elicited marked cytotoxic effects in MCF-7 cells compared with the individual treatments, whereas when it was combined with Rau 015 and with Rau 018, it displayed similar effects in MDA-MB-231 cells. The anti-angiogenic effect of Rau 015 plus curcumin in MCF-7 cells and Rau 018 plus curcumin in $M D A-M B-231$ cells was more effective than individual treatments, while the metastatic capability of MDA-MB-231 cells was significantly reduced after treatment with the aminonaphthoquinone-curcumin combinations. Conclusion: Aminonaphthoquinones may offer significant promise as therapeutic agents against breast cancer, particularly when combined with curcumin.
\end{abstract}

Correspondence to: Hajierah Davids, Ph.D., Department of Physiology, Nelson Mandela University, Port Elizabeth, 6031, South Africa. Tel: +27 415042019, e-mail: hajierah.davids@mandela.ac.za

Key Words: Aminonaphthoquinone, curcumin, combination, cytotoxic, anti-angiogenic, anti-metastatic.
Cancer elicits great suffering and economic loss world-wide (1). In 2018, the world-wide affliction of cancer rose to an estimated 18 million new cases with a concomitant 9.6 million deaths resulting from cancer (2). Worldwide, in 2018, the most common cancer types diagnosed were those of the lung, followed by breast and prostate (2). Breast cancer is the most commonly diagnosed cancer in women worldwide $(3,4)$, with approximately two-thirds of all breast cancer cases classified as oestrogen receptor-positive or $\mathrm{ER}^{+}(5)$.

The leading cause of death among women with breast cancer is attributed to metastasis (6), which involves the adhesion of tumour cells to the extracellular matrix (ECM) and subsequent invasion and migration of these cells within the bloodstream to distant sites, leading to the formation of secondary tumours in non-breast tissue (7-9). Metastasis relies predominantly on angiogenesis, a tightly-regulated process that involves the formation of new blood vessels from existing vasculature (10). Angiogenesis plays a vital role in biological processes such as reproduction, embryonic development and wound healing. This includes tumour development and progression, since it provides both a vascular supply as well as nutrients (such as growth factors and oxygen) to the growing tumour (11). The crucial role of angiogenesis in the development and progression of cancer makes it an important target in the treatment of cancer (12). Vascular endothelial growth factor (VEGF) is the main inducer of tumour angiogenesis and amplifies the expression of local proteases that degrade the ECM, in addition to being the most effective factor that promotes vasodilation of the existing vessels and increases the permeability of the vessel wall (12-14).

Although metastasis may be directed to several tissues, the most common site of breast cancer metastasis is the bone, as certain hormone-responsive breast tumours have a greater propensity to metastasize to bone than to the viscera (15-17). 
The selective oestrogen modulator, tamoxifen, is extensively used to treat all stages of $\mathrm{ER}^{+}$breast cancer (18); however, the long-term efficacy of selective oestrogen modulators is limited by disease recurrence and tumour resistance (19). Moreover, tamoxifen acts agonistically in endometrial tissue, which is linked to an increased incidence of endometrial cancer $(20,21)$.

While some targeted therapies are associated with enhanced therapeutic effects, in most cases, these effects are not sustainable when used as monotherapy, due to the development of drug resistance or clinical relapse $(22,23)$. Combination therapies are thus often used to treat cancer more effectively, since the action of multiple drugs may involve different mechanisms or modes of action, and can be directed at multiple targets, thereby resulting in higher therapeutic efficacy (24).

One avenue of cancer research that has shown promise is that of the plant phenols, since these compounds target multiple pathways to achieve cellular death (25). A well-studied example is curcumin, the active constituent of turmeric $(25,26)$. Curcumin is notable for its widely accepted pharmacological safety and broad range of biological activities that include antioxidant, anti-inflammatory, antiviral, antifungal, antibacterial, anticancer, antidiabetic, and neuroprotective properties (27-33). Despite several reports challenging the efficacy of curcumin as a potential anticancer agent (34-36), curcumin inhibits various cell proliferation signalling pathways that are activated during cancer progression (37), while increasing the expression of various tumour-suppressor and proapoptotic factors $(38,39)$. Moreover, curcumin inhibits angiogenic factor expression (40) and restricts metastasis by targeting several adhesion-, invasion- and migration-related factors (41). Nonetheless, its therapeutic use is limited as it is insoluble in water and undergoes photodegradation, leading to low bioavailability (42). In this regard, several formulations have been designed with curcumin, as described by Prasad et al., where the delivery, bioavailability and metabolism of curcumin and its formulations are explored (43).

Studies involving aminonaphthoquinones have yielded promising results (44-46). In this study, four novel, synthetic aminonaphthoquinone derivatives (46), coded Rau 008, Rau 010, Rau 015 and Rau 018 (Figure 1), were analysed in combination with curcumin for their potential as cytotoxic, anti-angiogenic and anti-metastatic agents against breast cancer. Previous studies of these compounds combined with curcumin showed significant anticancer effects in ERdependent and ER-independent breast cancer cells, including other oestrogen-responsive tumour cell lines (46).

This study aimed to determine the combinatory effects of the Rau compounds with curcumin on the progression of $\mathrm{ER}^{+}(\mathrm{MCF}-7)$ and $\mathrm{ER}^{-}$(MDA-MB-231) breast cancer cells. In this regard, we examined the effect of the combinations on: i) Cell viability, ii) levels of VEGF iii) the ability of
MCF-7 and MDA-MB-231 breast cancer cells to adhere predominant ECM proteins (47), and the iv) invasive and v) migratory potential of MDA-MB-231 breast cancer cells, which is considered to be highly metastatic $(48,49)$.

\section{Materials and Methods}

Cell culture and maintenance. The cell lines (MCF-7 and MDAMB-231) were obtained from the National Institute of Biomedical Innovation (Osaka, Japan). Cells were grown in complete growth medium consisting of Dulbecco's minimal essential medium (DMEM; Hyclone Ltd., Northumberland, UK) supplemented with $10 \%$ foetal bovine serum (Hyclone Ltd.). The cells were subcultured every 3-4 days and were incubated at $37^{\circ} \mathrm{C}$ in a humidified incubator with $5 \% \mathrm{CO}_{2}$ and $95 \%$ air.

Preparation of compounds and controls. The synthesis of the Rau compounds (45), including the spectroscopic analysis of Rau 008 (50), Rau 010 (45), Rau 015 (51) and Rau 018 (45), have been reported previously. Drug interactions between the Rau compounds and curcumin in MCF-7 breast cancer cells were initially investigated in our laboratory (46), using combination index (5255) and isobologram (56) approaches. Accordingly, drug combinations displaying potential synergistic or additive interactions (46) were selected for further analyses in this study.

Stock solutions of the Rau compounds, curcumin (SigmaAldrich, Munich, Germany) and tamoxifen (Sigma-Aldrich) were prepared at $100 \mathrm{mM}$ in 100\% dimethyl sulfoxide (DMSO; SigmaAldrich). Similarly, $17 \beta$-oestradiol (Sigma-Aldrich) was prepared using absolute ethanol (Sigma-Aldrich). The final well concentration of DMSO or ethanol in treated or control samples was $0.15 \% \mathrm{v} / \mathrm{v}$, which did not affect cell growth (46). Dilutions (at final well concentrations ranging from 15 to $120 \mu \mathrm{M}$ ) of agents were prepared fresh from stock solutions with complete growth medium.

Cell viability studies. The cytotoxicity of the test compounds and controls was determined using the 3-(4,5-dimethylthiazol-2-yl)-2,5diphenyltetrazolium bromide (MTT) assay (57). Cells were harvested after reaching $80 \%$ confluence and seeded at a density of $1 \times 10^{4}$ cells per well in complete growth medium, in 96-well tissue culture plates. After an overnight incubation at $37^{\circ} \mathrm{C}$, cells were treated with the Rau compounds/controls (tamoxifen or $17 \beta$ oestradiol), alone and in combination with curcumin, at final well concentrations ranging from 15 to $120 \mu \mathrm{M}$. Vehicle controls $(0.15 \%$ DMSO or $0.15 \%$ ethanol), as well as an untreated control, were included. The cells were incubated at $37^{\circ} \mathrm{C}$ for $24 \mathrm{~h}$, followed by removal of the conditioned media and subsequent storage at $-80^{\circ} \mathrm{C}$ for VEGF determinations. Thereafter, MTT $(0.5 \mathrm{mg} / \mathrm{ml}, 100 \mu \mathrm{l}$; Duchefa Biochemie, Haarlem, the Netherlands) was added to each well and the plates were incubated for $3 \mathrm{~h}$ at $37^{\circ} \mathrm{C}$. The purple formazan product formed was solubilised in 100\% DMSO $(200 \mu \mathrm{l})$ and the absorbance read at $540 \mathrm{~nm}$ using a microtitre plate reader (Bio-Tek Instruments Inc., Winooski, VT, USA), against a DMSO blank. Data were normalized to the cell number using a cell number standard curve and the proportion of viable cells was expressed as a percentage of the $0.15 \%$ DMSO or $0.15 \%$ ethanol (for $17 \beta$ oestradiol) vehicle-treated controls.

Angiogenic studies. The concentration of VEGF in cell supernatants was quantified using Invitrogen human VEGF ELISA kit 
<smiles>[R]O[Na]</smiles><smiles></smiles><smiles></smiles><smiles>[R10][R10]#[R]</smiles>

Figure 1. Structures and name codes of the aminonapthoquinones used in the anticancer analyses (46).

(Invitrogen, Carlsbad, CA, USA), according to the manufacturer's instructions.

Adhesion assay. The cell adhesion assay was performed as previously described (58), with slight modifications. Briefly, 96-well tissue culture plates were coated with $5 \mu \mathrm{g} / \mathrm{ml}$ fibronectin (B.D. Biosciences, San Jose, CA, USA), $5 \mu \mathrm{g} / \mathrm{ml}$ collagen (SigmaAldrich) or $5 \mu \mathrm{g} / \mathrm{ml}$ laminin (Sigma-Aldrich), and left overnight at $4^{\circ} \mathrm{C}$. The plates were rinsed with $0.1 \mathrm{M}$ phosphate-buffered saline (PBS, $\mathrm{pH}$ 7.4) and blocked with $1 \%$ bovine serum albumin (BSA, in $0.1 \mathrm{M}$ PBS, $\mathrm{pH} 7.4)$ for $30 \mathrm{~min}$ at $37^{\circ} \mathrm{C}$. Cells $\left(1 \times 10^{5}\right.$ cells/well $)$ in $100 \mu \mathrm{l}$ serum-free DMEM were added to pre-coated wells and incubated with the Rau compounds/controls, alone and in combination with curcumin, at final well concentrations ranging from 15 to $120 \mu \mathrm{M}$ for $2 \mathrm{~h}$ at $37^{\circ} \mathrm{C}$. Non-adherent cells were removed by rinsing with PBS. Adherent cells were fixed with $95 \%$ ethanol for $5 \mathrm{~min}$, rinsed three times with PBS and stained with 100 $\mu \mathrm{l}$ crystal violet solution $(0.5 \% \mathrm{w} / \mathrm{v}$ crystal violet in $20 \%$ ethanol) for $10 \mathrm{~min}$. Excess stain was removed with distilled water and extraction solution (100 $\mu 110 \%$ acetic acid) was added to each well. The absorbance was read at $590 \mathrm{~nm}$ using a microplate reader (BioTek Instruments Inc., Winooski, VT, USA) against the extraction solution blank. The number of attached cells was ascertained by interpolation from a cell number standard curve and expressed as a percentage of the $0.15 \%$ DMSO or $0.15 \%$ ethanol (for $17 \beta$ oestradiol) vehicle-treated control.

Invasion assay. The effects of the various treatments on the invasive ability of MDA-MB-231 cells was determined using CytoSelect ${ }^{\mathrm{TM}}$ 96-Well Cell Invasion Assay kit (Cell Biolabs Inc., San Diego, CA, USA) according to the manufacturer's instructions.

Cell migration analysis. A Boyden chamber migration assay was performed as previously described $(59,60)$, with slight modifications. For this assay, Transwell cell culture inserts $(6.5 \mathrm{~mm}$ diameter, $8 \mu \mathrm{m}$ pore) in a 24 -well format were used (Corning Costar, NY, USA). Confluent MDA-MB-231 cells, which were serumstarved for $24 \mathrm{~h}$, were harvested and resuspended at $1 \times 10^{6}$ cells $/ \mathrm{ml}$ in serum-free DMEM. Medium (500 $\mu$ ) containing 10\% FBS (which served as the chemoattractant) was added to the lower well of the migration plate. The test compounds were prepared using serum-free DMEM in a 96 -well plate $(100 \mu \mathrm{l})$ to which $100 \mu \mathrm{l}$ cell suspension $\left(1 \times 10^{6}\right.$ cells $\left./ \mathrm{ml}\right)$ was added. The cell suspension and test compounds (at final well concentrations ranging from 15 to $120 \mu \mathrm{M}$ ) were thoroughly mixed before transferring $100 \mu \mathrm{l}$ aliquots to the inside of each insert. After a $6 \mathrm{~h}$ incubation at $37^{\circ} \mathrm{C}$, the medium was carefully aspirated from the inside of the insert, while non-migratory cells were carefully removed with wet cotton-tipped swabs. Migratory cells on the lower side of the insert membrane were fixed with icecold $95 \%$ ethanol and left at room temperature for $10 \mathrm{~min}$. The inserts were washed three times with 0.1 M PBS ( $\mathrm{pH} 7.4$ ), followed by staining with $200 \mu \mathrm{l} 0.5 \%$ crystal violet solution and subsequent incubation at room temperature for $10 \mathrm{~min}$. The stained inserts were washed thrice in distilled water, allowed to air dry and transferred to a new well containing $200 \mu \mathrm{l}$ extraction solution (10\% acetic acid) for a further $10 \mathrm{~min}$. Thereafter, the inserts were removed and the absorbance of the solubilised crystal violet was read at $590 \mathrm{~nm}$ using a microtitre reader (Bio-Tek Instruments Inc., Winooski, VT, U.S.A.) against the extraction solution blank. Results were normalized to cell number, and the number of migrated cells following treatment was calculated as a percentage of the $0.15 \%$ DMSO or $0.15 \%$ ethanol vehicle control.

Statistical analysis. Data are presented as the mean \pm SD of three experiments $(n=3)$. Differences between experimental groups and controls were analysed for significance using Student's $t$-test. Values of $p<0.05$ were considered statistically significant.

\section{Results}

Cell viability analyses. The effect of the various treatments on cell viability was analysed using the MTT assay. In MCF7 cells, all combination treatments reduced cell viability significantly in relation to the vehicle control $(p<0.05)$ (Figure 2). The inhibition elicited by Rau 008-curcumin was more effective than Rau $008(p=0.0182)$ or curcumin alone $(p=0.0027)$. Similarly, tamoxifen-curcumin proved more cytotoxic than either agent alone ( $p<0.05$, respectively). Furthermore, the cytotoxicity exerted by Rau 008-curcumin, Rau 015-curcumin, Rau 018-curcumin and tamoxifencurcumin appeared more significant than that of $17 \beta$ oestradiol-curcumin ( $p<0.05$, respectively). The viability of MDA-MB-231 cells (Figure 2) was significantly reduced following treatment with the Rau-curcumin combinations $(p<0.05$, compared to the vehicle control). Moreover, the inhibitory effect of these combinations was more marked compared to treatment with tamoxifen-curcumin or $17 \beta$ oestradiol-curcumin ( $p<0.005$, respectively). Notably, combinatory treatment with Rau 015-curcumin or Rau 018curcumin resulted in enhanced cytotoxic effects compared to treatment with the individual compounds $(p<0.05$, respectively). However, treatment with $17 \beta$-oestradiolcurcumin did not significantly affect cell viability in relation to the vehicle control $(p=0.2247)$.

Influence of combinatory treatments on the induction of angiogenesis. To determine the effect of the combinatory 


\section{MCF-7 cells}

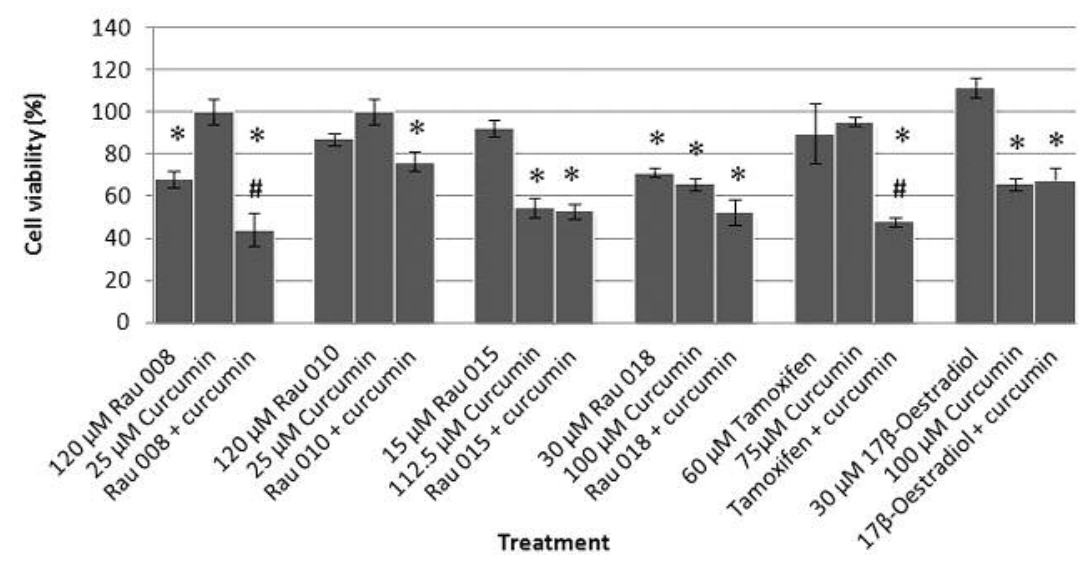

MDA-MB-231 cells

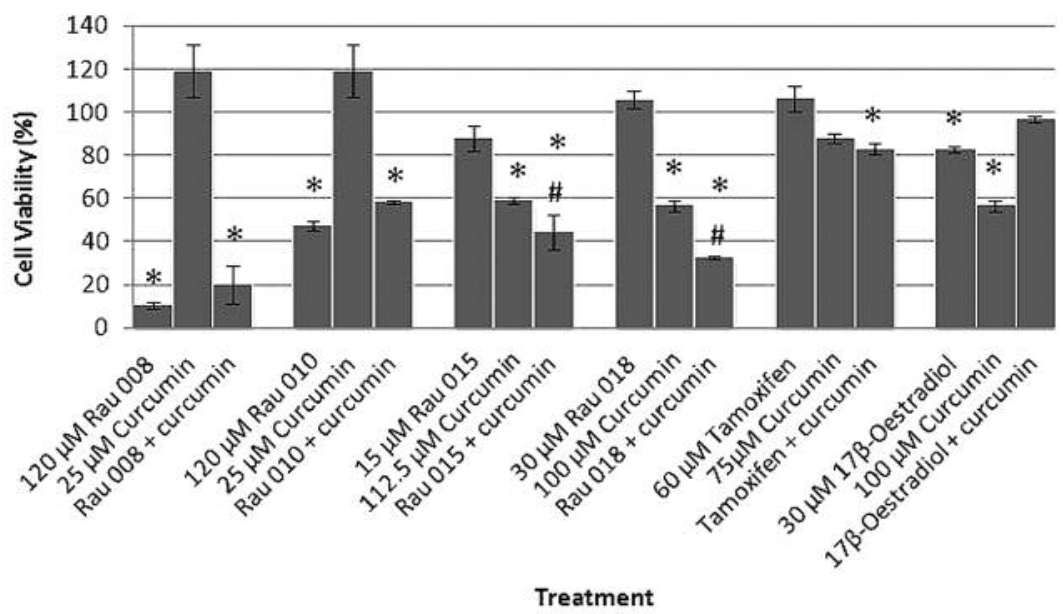

Figure 2. Cytotoxicity of the various treatments in MCF-7 and MDA-MB-231 breast cancer cells. The number of viable cells is presented as a percentage of the vehicle control $(0.15 \%$ dimethyl sulfoxide or $0.15 \%$ ethanol). The viability of the cells treated with vehicle control was not significantly different compared to that of the untreated control $(p>0.05)$, and was therefore set at $100 \%$ (not shown). Data are reported as

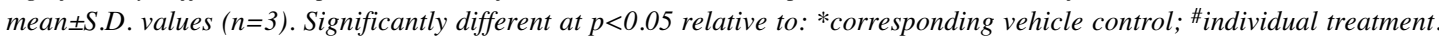

treatments on the induction of angiogenesis in breast cancer cells, the VEGF level was determined. In MCF-7 cells, Rau 015-curcumin and tamoxifen-curcumin reduced the VEGF level significantly compared to the DMSO vehicle control $(p<0.05)$, and exerted an enhanced anti-angiogenic effect in relation to individual treatment ( $p<0.05$, respectively) (Figure $3)$. It is noteworthy that treatment with Rau $015(15 \mu \mathrm{M})$, Rau $018(30 \mu \mathrm{M})$ and $17 \beta$-oestradiol $(30 \mu \mathrm{M})$ significantly increased the VEGF level compared to the relevant vehicle controls $(p<0.05)$, indicating that these compounds may promote angiogenesis in $\mathrm{ER}^{+}$breast cancer. In MDA-MB-231 cells, all Rau-curcumin combinations reduced the level of VEGF $(p<0.05)$, with Rau 018-curcumin inhibiting the
VEGF level more effectively than Rau 018 and curcumin alone ( $p<0.05$, respectively). Notably, treatment with $60 \mu \mathrm{M}$ tamoxifen or $30 \mu \mathrm{M} 17 \beta$-oestradiol significantly increased the VEGF level compared to the relative vehicle controls $(p<0.05)$, whereas the effect of tamoxifen-curcumin and of $17 \beta$-oestradiol-curcumin on the VEGF level was not significant ( $p>0.05$, respectively) (Figure 3).

Influence of combinatory treatments on the ability of MCF7 and MDA-MB-231 cells to adhere to different ECM substrates. To determine if the combinations impeded the ability of MCF-7 and MDA-MB-231 cells to adhere to different ECM substrates, an adhesion assay was performed. 

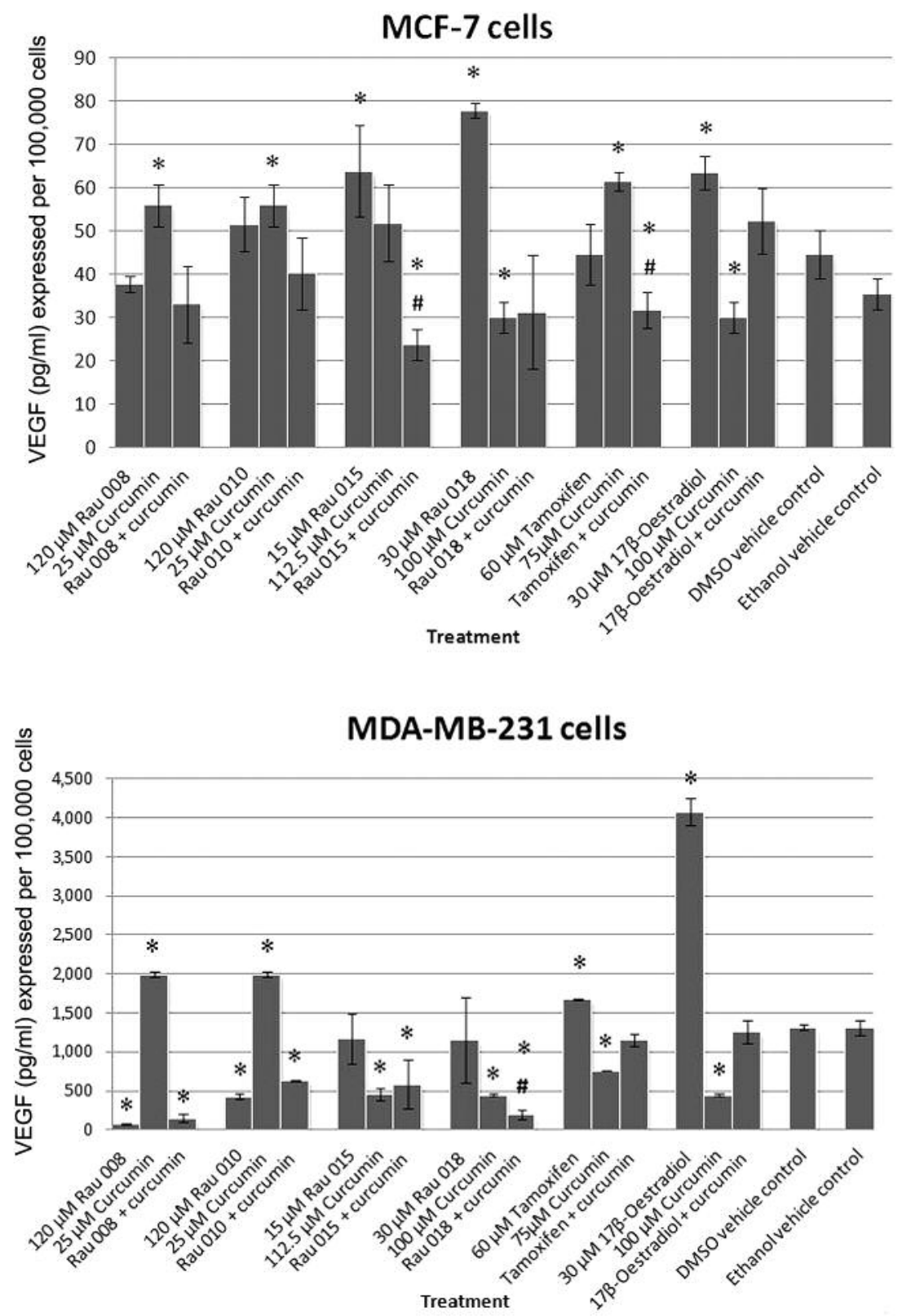

Figure 3. Effect of treatments on vascular endothelial growth factor levels (VEGF) in MCF-7 and MDA-MB-231 cells. VEGF levels were normalised by cell number and are reported as the mean \pm S.D. values $(n=3)$. Significantly different at $p<0.05$ relative to: *corresponding vehicle control; \#individual treatment.

As indicated in Table I, Rau 015-curcumin, Rau 018curcumin, tamoxifen-curcumin and $17 \beta$-oestradiol-curcumin significantly reduced the attachment of MCF-7 cells to fibronectin, collagen and laminin in relation to the vehicle control $(p<0.05)$, however, these inhibitory effects were similar to those of curcumin alone ( $p>0.05$, respectively). Furthermore, these combinations were more effective at reducing the attachment of MCF-7 cells to the different ECM substrates than treatment with Rau 008-curcumin and Rau 010-curcumin $(p<0.05)$. In MDA-MB-231 cells, all combination treatments significantly reduced cell attachment to the different ECM substrates $(p<0.05)$ (Table I). It is evident that the anti-adhesive effects displayed by Rau 010curcumin to fibronectin, Rau 018-curcumin to collagen, and Rau 008-curcumin or 17 $\beta$-oestradiol-curcumin to laminin was more effective than individual treatment $(p<0.05)$. 
Table I. Effect of the compounds and their combinations with curcumin on the ability of MCF-7 and MDA-MB-231 cells to adhere to various substrates. Experimental details are presented in the Materials and Methods section. The number of attached cells was expressed as a percentage of the $0.15 \%$ dimethyl sulfoxide or $0.15 \%$ ethanol vehicle control and is reported as the mean $\pm S . D(n=3)$. The vehicle control did not affect cell adhesion significantly compared to the untreated control ( $p>0.05$, data not shown), and the percentage of attached cells was therefore considered

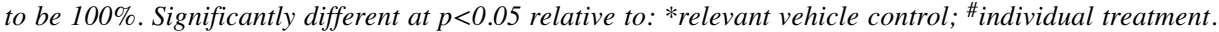

\begin{tabular}{|c|c|c|c|c|c|c|}
\hline \multirow[b]{2}{*}{ Treatment } & \multicolumn{3}{|c|}{ MCF-7 cells } & \multicolumn{3}{|c|}{ MDA-MB-231 cells } \\
\hline & Fibronectin & Collagen & Laminin & Fibronectin & Collagen & Laminin \\
\hline $120 \mu \mathrm{M}$ Rau 008 & $74.04 \pm 5.09^{*}$ & $82.57 \pm 5.37$ & $90.83 \pm 4.20$ & $15.26 \pm 8.91 *$ & $76.98 \pm 4.66^{*}$ & $100.68 \pm 15.32$ \\
\hline $25 \mu \mathrm{M}$ Curcumin & $88.36 \pm 9.15$ & $104.82 \pm 5.96$ & $101.85 \pm 7.74$ & $71.77 \pm 14.96 *$ & $95.77 \pm 5.98$ & $92.86 \pm 21.65$ \\
\hline Rau $008+$ curcumin & $82.59 \pm 1.88 *$ & $94.81 \pm 3.20$ & $101.45 \pm 4.19$ & $41.55 \pm 14.72 *$ & $85.22 \pm 5.52 *$ & $56.12 \pm 4.33^{* \#}$ \\
\hline $120 \mu \mathrm{M}$ Rau 010 & $86.54 \pm 1.36^{*}$ & $106.80 \pm 7.98$ & $112.67 \pm 4.50$ & $64.33 \pm 6.12 *$ & $55.61 \pm 19.10 *$ & $91.16 \pm 13.59$ \\
\hline $25 \mu \mathrm{M}$ Curcumin & $88.36 \pm 9.15$ & $104.82 \pm 5.96$ & $101.85 \pm 7.74$ & $71.77 \pm 14.96^{*}$ & $95.77 \pm 5.98$ & $92.86 \pm 21.65$ \\
\hline Rau $010+$ curcumin & $80.98 \pm 2.69^{*}$ & $95.30 \pm 2.26$ & $102.77 \pm 3.00$ & $22.75 \pm 3.88^{* \#}$ & $59.61 \pm 11.36^{*}$ & $65.99 \pm 6.56^{*}$ \\
\hline $15 \mu \mathrm{M}$ Rau 015 & $80.70 \pm 3.99^{*}$ & $96.15 \pm 5.91$ & $86.81 \pm 3.35$ & $92.11 \pm 11.17$ & $81.47 \pm 10.05^{*}$ & $35.42 \pm 4.51^{*}$ \\
\hline $112.5 \mu \mathrm{M}$ Curcumin & $29.82 \pm 1.99 *$ & $40.15 \pm 1.88^{*}$ & $32.91 \pm 47.45^{*}$ & $76.97 \pm 2.79 *$ & $65.42 \pm 1.62 *$ & $31.77 \pm 5.02 *$ \\
\hline Rau 015 + curcumin & $26.32 \pm 2.41^{*}$ & $44.00 \pm 4.81^{*}$ & $40.85 \pm 6.00 *$ & $73.03 \pm 2.79^{*}$ & $71.19 \pm 5.60 *$ & $42.97 \pm 1.10^{*}$ \\
\hline $30 \mu \mathrm{M}$ Rau 018 & $79.30 \pm 4.97 *$ & $87.29 \pm 9.10$ & $77.85 \pm 6.03^{*}$ & $112.03 \pm 13.29$ & $81.03 \pm 1.45^{*}$ & $64.06 \pm 6.63^{*}$ \\
\hline $100 \mu \mathrm{M}$ Curcumin & $24.39 \pm 3.50 *$ & $42.24 \pm 7.78^{*}$ & $33.80 \pm 2.40 *$ & $53.20 \pm 15.68 *$ & $94.41 \pm 0.66$ & $28.91 \pm 1.10^{*}$ \\
\hline Rau 018 + curcumin & $26.14 \pm 1.10^{*}$ & $43.89 \pm 4.62 *$ & $36.11 \pm 4.72 *$ & $61.56 \pm 8.91 *$ & $55.35 \pm 1.50 * \#$ & $28.65 \pm 8.02 *$ \\
\hline $60 \mu \mathrm{M}$ Tamoxifen & $36.54 \pm 4.02 *$ & $39.49 \pm 10.23 *$ & $37.60 \pm 3.09 *$ & $5.49 \pm 0.69 *$ & $51.68 \pm 4.60^{*}$ & $22.45 \pm 2.89 *$ \\
\hline $75 \mu \mathrm{M}$ Curcumin & $40.17 \pm 1.03^{*}$ & $48.46 \pm 2.78^{*}$ & $36.94 \pm 2.18^{*}$ & $51.80 \pm 9.93^{*}$ & $52.75 \pm 5.38 *$ & $94.90 \pm 12.99$ \\
\hline Tamoxifen + curcumin & $27.35 \pm 3.88^{*}$ & $46.35 \pm 5.77 *$ & $35.49 \pm 3.96^{*}$ & $48.43 \pm 7.49^{*}$ & $68.52 \pm 11.24^{*}$ & $51.02 \pm 8.66^{*}$ \\
\hline $30 \mu \mathrm{M} 17 \beta$-Oestradiol & $94.62 \pm 6.64$ & $91.51 \pm 4.48$ & $104.10 \pm 8.75$ & $104.76 \pm 3.45$ & $131.94 \pm 23.82$ & $117.85 \pm 9.11$ \\
\hline $100 \mu \mathrm{M}$ Curcumin & $24.39 \pm 3.50 *$ & $42.24 \pm 7.78^{*}$ & $33.80 \pm 2.40^{*}$ & $53.20 \pm 15.68^{*}$ & $94.41 \pm 0.66$ & $28.91 \pm 1.10^{*}$ \\
\hline $17 \beta-$-Oestradiol + curcumin & $28.07 \pm 3.08^{*}$ & $41.69 \pm 1.69^{*}$ & $32.97 \pm 4.43^{*}$ & $63.00 \pm 22.06^{*}$ & $69.65 \pm 18.78^{*}$ & $14.06 \pm 2.21^{* \#}$ \\
\hline
\end{tabular}

Influence of combinatory treatments on the invasive ability of MDA-MB-231 breast cancer cells. The percentage of invasive cells for the untreated control $(18.41 \pm 4.43 \%$, not shown) was comparable with findings by Booden et al. (49) and Sieuwerts et al. (60), who established an invasive potential of approximately $22-23 \%$ for unstimulated MDAMB-231 cells. The invasive potential of the DMSO and ethanol vehicle controls was $27.73 \pm 6.38 \%$ and $23.56 \pm 2.90 \%$, respectively (Figure 4$)$. These results were not significantly different compared to the untreated control $(p>0.05$, not shown), showing that $0.15 \%$ DMSO and $0.15 \%$ ethanol did not affect the invasive potential of the MDA-MB-231 cells. Combinations of Rau 010, Rau 015, tamoxifen and 17 $\beta$ oestradiol with curcumin significantly reduced the invasive ability of MDA-MB-231 cells compared to the vehicle control $(p<0.05)$, whilst tamoxifen-curcumin showed a more enhanced anti-invasive effect than tamoxifen and curcumin alone ( $p<0.05$, respectively) (Figure 4$)$.

Effect of combinatory treatments on the migratory potential of MDA-MB-231 cells. All the test compounds (except 17 $\beta$ oestradiol) significantly reduced the migratory potential of MDA-MB-231 cells ( $p<0.05$, Figure 5). Individual treatment with the Rau compounds or curcumin was as effective as combined treatment $(p>0.05)$, with a similar trend noted after treatment with tamoxifen or curcumin $(p>0.05)$.
Although the effect of $17 \beta$-oestradiol-curcumin was as effective as that of curcumin alone $(p>0.05)$, it should be noted that this combination was highly effective at reducing the migration of MDA-MB-231 cells compared to the effect of $17 \beta$-oestradiol alone $(p<0.05)$.

\section{Discussion}

The high incidence of adverse effects induced by the majority of currently available chemotherapeutics has motivated extensive investigations of alternative treatments, particularly combination therapies (24). In this study, we investigated the combination effects of novel aminonapthoquinone derivatives and curcumin on the progression of breast cancer cells. The combination ratios analysed were selected based on drug interactions between the Rau compounds and curcumin in ER+ breast cancer cells (46).

The results from this study suggest that the test agents may offer significant promise as therapeutic agents against both $\mathrm{ER}^{+}$and $\mathrm{ER}^{-}$cancer, particularly when combined with curcumin. In this regard, it was shown that Rau $008(120 \mu \mathrm{M})$, in combination with curcumin $(25 \mu \mathrm{M})$, induced a marked cytotoxic effect in $\mathrm{ER}^{+}$breast cancer cells (Figure 2), in addition to reducing the attachment of $\mathrm{ER}^{-}$breast cancer cells to laminin more effectively than individual treatment (Table I). Curcumin $(25 \mu \mathrm{M})$ was shown to augment the anti- 


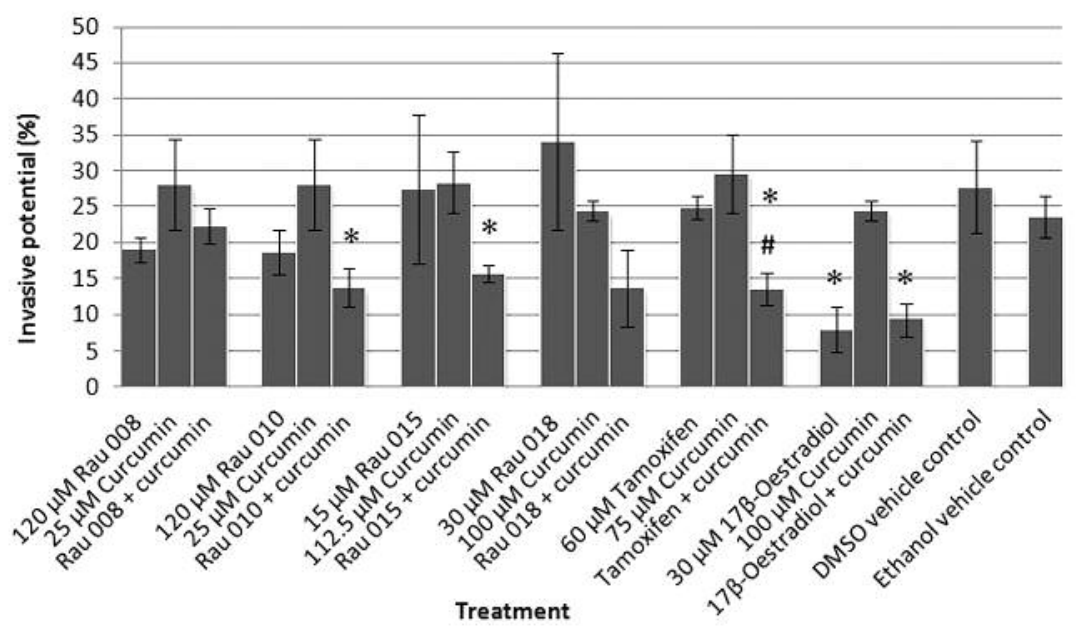

Figure 4. Effect of treatments on the invasive potential of MDA-MB-231 cells. The number of invading cells present on the bottom side of the filter was expressed as a percentage of the total number of cells (sum of cells present in the basement membrane and on the bottom side of the filter) and is indicated as the invasive potential. Results are reported as the mean \pm S.D. values $(n=3)$. Significantly different at $p<0.05$ relative to: *corresponding vehicle control; \#individual treatment.

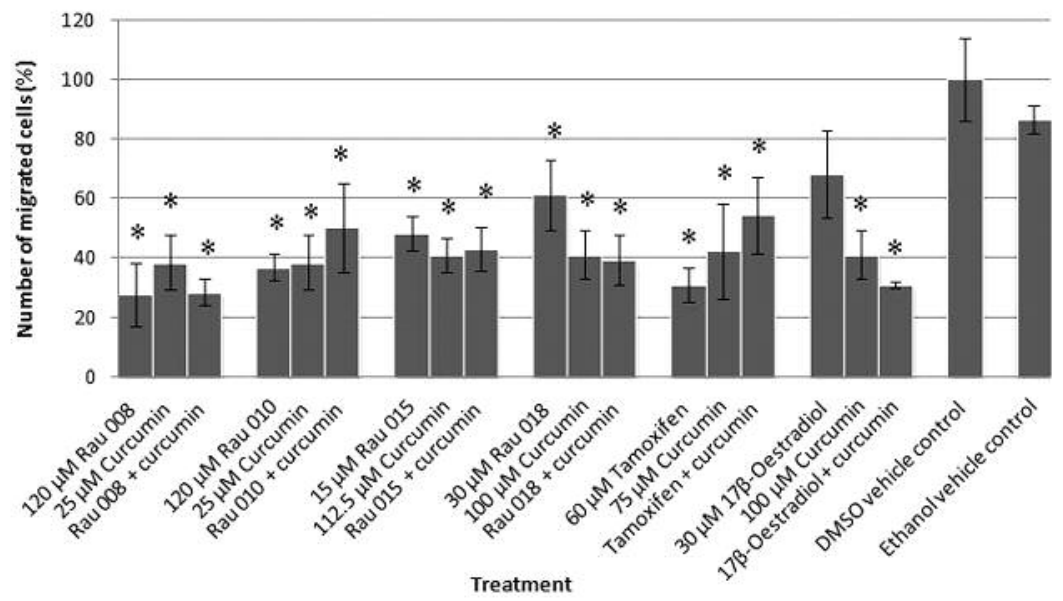

Figure 5. Effect of treatments on the migratory potential of MDA-MB-231 cells. The number of migrated cells was expressed as a percentage of the $0.15 \%$ DMSO or $0.15 \%$ ethanol vehicle control and is reported as the mean $\pm S . D(n=3)$. *Significantly different at $p<0.05$ relative to the corresponding vehicle control.

metastatic effect of Rau $010(120 \mu \mathrm{M})$ in $\mathrm{ER}^{-}$breast cancer cells by enhancing its anti-adhesive effect to fibronectin (Table I), in addition to reducing the invasive potential of these cells (Figure 4). Rau $015(15 \mu \mathrm{M})$, in combination with curcumin $(112.5 \mu \mathrm{M})$, caused increased cytotoxicity in ER- breast cancer cells (Figure 2), exerted a marked anti-angiogenic effect on $\mathrm{ER}^{+}$breast cancer cells (Figure 3 ) and attenuated the invasive potential of $\mathrm{ER}^{-}$breast cancer cells (Figure 4). The sensitivity of $\mathrm{ER}^{-}$breast cancer cells to Rau $018(30 \mu \mathrm{M})$ was enhanced when combined with curcumin $(100 \mu \mathrm{M})$ by exerting enhanced cytotoxic (Figure 2 ) and anti-angiogenic effects (Figure 3), as well as strong anti-adhesive effects to collagen (Table I). These results correlate with our previous finding that pointed to the influence of curcumin in the responsiveness of $\mathrm{ER}^{+}$and $\mathrm{ER}^{-}$tumours towards these compounds (46).

It is important to highlight the fact that curcumin $(75 \mu \mathrm{M})$ enhanced the effect of tamoxifen $(60 \mu \mathrm{M})$ in $\mathrm{ER}^{+}$breast cancer (Figures 2 and 3), while also reducing the invasive potential of $\mathrm{ER}^{-}$breast cancer more effectively than treatment with tamoxifen or curcumin alone (Figure 4). Our finding that tamoxifen lacked a significant cytotoxic effect 
in MCF-7 cells (Figure 2) is comparable with findings from a combination study investigating the cytotoxic effects of tamoxifen with nordamnacanthal on the MCF-7 cell line (61). The authors found that treatment with tamoxifen alone for $24 \mathrm{~h}$ reduced the viability of $\mathrm{MCF}-7$ cells by approximately $12 \%$, however, this effect was not significant compared to the control. Conversely, a combination of nordamnacanthal and tamoxifen reduced MCF-7 cell viability by up to $77.0 \%$ (61). The significance of the antiinvasive effect of tamoxifen in breast cancer has been reported in another study investigating the effects of tamoxifen and a known anti-allergic drug, tranilast, where it was found that tamoxifen $(2 \mu \mathrm{M})$, alone or in combination with tranilast $(200 \mu \mathrm{M})$, reduced the invasive and metastatic capability of MCF-7 and MDA-MB-231 breast cancer cells by down-regulation of the expression level of the chemokine receptor protein $\mathrm{C}-\mathrm{X}-\mathrm{C}$ motif chemokine receptor 4 (CXCR4), and its ligand CXCL12 (62). This anti-invasive effect of tamoxifen does not correlate with our findings; however, this inconsistency might be due to differences in assay conditions. Nonetheless, our findings point to the efficacy of tamoxifen $(60 \mu \mathrm{M})$ with curcumin $(75 \mu \mathrm{M})$ against $\mathrm{ER}^{+}$breast cancer, as well as against $\mathrm{ER}^{-}$breast cancer. The higher therapeutic efficacy of tamoxifencurcumin compared to that of tamoxifen alone suggests that curcumin could be beneficial if used in addition to chemotherapeutic drugs, and this warrants further investigation.

The observation that a combination of $17 \beta$-oestradiol $(30 \mu \mathrm{M})$ and curcumin $(100 \mu \mathrm{M})$ reduced the attachment of $\mathrm{ER}^{-}$breast cancer cells to laminin more effectively than individual treatment (Table I) indicates that this combination may serve as a therapeutically useful tool against ER-independent breast cancer, and also requires further investigation.

This study proposed that selected combinations of synthetic aminonaphthoquinone derivatives with curcumin might impede angiogenesis and metastasis, important factors affecting the progression of breast cancer. It was established that the combinations show promise as potential therapeutic agents against breast cancer and warrant further investigation. Future studies should involve mechanistic studies to identify putative targets of the relative drug combinations, as well as in-depth in vivo toxicity analyses to predict the efficacy of these treatments for therapeutic benefit. Furthermore, the absorption and bioavailability of curcumin should also be explored, so that curcumin-based combinations or derivatives can be used as an adjuvant to current chemotherapy regimens.

\section{Conflicts of Interest}

The Authors declare no conflicts of interest in regard to this study.

\section{Authors' Contributions}

Melanie C. Pereira designed the study, performed all the experiments, analysed the results and wrote the article. Hajierah Davids supervised the study and edited the article. Raushaan Mohammed synthesized the test compounds under the supervision of Willem A.L. Van Otterlo and Charles B. De Koning. Hajierah Davids, Willem A.L. Van Otterlo and Charles B. De Koning revised and approved the final article.

\section{Acknowledgements}

This study was funded by the National Research Foundation, NRFThuthuka Grant 87902, Pretoria, South Africa and Nelson Mandela University, Port Elizabeth, South Africa. C. de Koning and W. van Otterlo gratefully acknowledge NRF research funding and the University of the Witwatersrand and Stellenbosch University for support.

\section{References}

1 Prager GW, Braga S, Bystricky B, Qvortrup C, Criscitiello C, Esin E, Sonke GS, Martínez GA, Frenel JS, Karamouzis M, Strijbos M, Yazici O, Bossi P, Banerjee S, Troiani T, Eniu A, Ciardiello F, Tabernero J, Zielinski CC, Casali PG, Cardoso F, Douillard JY, Jezdic S, McGregor K, Bricalli G, Vyas M and Ilbawi A: Global cancer control: Responding to the growing burden, rising costs and inequalities in access. ESMO Open 3(2): e000285, 2018. PMID: 29464109. DOI: 10.1136/esmoopen2017-000285

2 Bray F, Ferlay J, Soerjomataram I, Siegel RL, Torre LA and Jemal A: Global cancer statistics 2018: GLOBOCAN estimates of incidence and mortality worldwide for 36 cancers in 185 countries. CA Cancer J Clin 68: 394-424, 2018. PMID: 30207593. DOI: $10.3322 /$ caac. 21492

3 Bellanger M, Zeinomar N, Tehranifar P and Terry M: Are global breast cancer incidence and mortality patterns related to countryspecific economic development and prevention strategies? J Glob Oncol, 2018. Available at https://ascopubs.org/doi/ full/10.1200/JGO.17.00207. Last accessed on 04 December 2019.

4 Ferlay J, Soerjomataram I, Ervik M, Dikshit R, Eser S, Mathers C, Rebelo M, Parkin DM, Forman D and Bray F: Cancer Incidence and Mortality Worldwide: IARC CancerBase No. 11 (Internet). France, International Agency for Research on Cancer, GLOBOCAN 2012 1(1), 2014. PMID: 25220842. DOI: $10.1002 /$ ijc. 29210

5 Lumachi F, Brunello A, Maruzzo M, Basso U and Basso SM: Treatment of estrogen receptor-positive breast cancer. Curr Med Chem 20(5): 596-604, 2013. PMID: 23278394. DOI: 10.2174/092986713804999303

$6 \mathrm{Yu} \mathrm{D}$ and Lu J: Breast Cancer Multistep Development. In: Encyclopedia of Cancer. Schwab M (ed.). Berlin, SpringerVerlag, pp. 522-526, 2011. DOI: 10.1007/978-3-642-16483-5

7 Lal I, Dittus K and Holmes CE: Platelets, coagulation and fibrinolysis in breast cancer progression. Breast Cancer Res 15: 207-218, 2013. PMID: 23905544. DOI: $10.1186 /$ bcr3425

8 Martin TA, Ye L, Sanders AJ, Lane J and Jiang WG: Cancer invasion and metastasis: Molecular and cellular perspective. In: 
Madame Curie Bioscience Database (Internet). Texas, Landes Bioscience, 2000-2013. Available at https://www.ncbi.nlm.nih. gov/books/NBK164700. Last accessed on 04 December 2019.

9 Chambers AF, Groom AC and MacDonald IC: Dissemination and growth of cancer cells in metastatic sites. Nat Rev Cancer 2: 563-572, 2002. PMID: 12154349. DOI: $10.1038 / \mathrm{nrc} 865$

10 Coomber BL, Yu JL, Fathers KE, Plumb C and Rak JW: Angiogenesis and the role of epigenetics in metastasis. Clin Exp Metast 20: 215-227, 2003. PMID: 12741680. DOI: 10.1023/ a:1022935117193

11 Hanahan D and Folkman J: Patterns and emerging mechanisms of the angiogenic switch during tumourigenesis. Cell 86: 353-364, 1996. PMID: 8756718 . DOI: $10.1016 / \mathrm{s} 0092-8674(00) 80108-7$

12 Niu G and Chen X: Vascular endothelial growth factor as an anti-angiogenic target for cancer therapy. Curr Drug Targets 11(8): 1000-1017, 2010. PMID: 20426765. DOI: 10.2174/ 138945010791591395

13 Bergers G, Brekken R, McMahon G, Vu TH, Itoh T, Tamaki K, Tanzawa K, Thorpe P, Itohara S, Werb Z and Hanahan D: Matrix metalloproteinase-9 triggers the angiogenic switch during carcinogenesis. Nat Cell Biol 2: 737-744, 2000. PMID: 11025665. DOI: $10.1038 / 35036374$

14 Ferrara $\mathrm{N}$ and Davis-Smyth $\mathrm{T}$ : The biology of vascular endothelial growth factor. Endocrine Rev 18: 4-25, 1997. PMID: 9034784. DOI: 10.1210/edrv.18.1.0287

15 Nguyen DX, Bos PD and Massagué J: Metastasis: From dissemination to organ-specific colonization. Nat Rev Cancer 9(4): 274-284, 2009. PMID: 19308067. DOI: 10.1038/nrc2622

16 Solomayer EF, Diel IJ, Meyberg GC, Gollan C and Bastert G: Metastatic breast cancer: Clinical course, prognosis and therapy related to the first site of metastasis. Breast Cancer Res Treat 59: 271-278, 2000. PMID: 10832597. DOI: 10.1023/a:1006308619659

17 Saphner T, Tormey DC and Gray R: Annual hazard rates of recurrence for breast cancer after primary therapy. J Clin Oncol 14: 2738-2746, 1996. PMID: 8874335. DOI: 10.1200/ JCO.1996.14.10.2738

18 Sengupta S and Jordan VC: Selective estrogen modulators as an anticancer tool: Mechanisms of efficiency and resistance. Adv Exp Med Biol 630: 206-219, 2008. PMID: 18637493. DOI: 10.1007/978-0-387-78818-0_13

19 Ring A and Dowsett M: Mechanisms of tamoxifen resistance. Endocr Relat Cancer 11(4): 643-658, 2004. PMID: 15613444. DOI: $10.1677 /$ erc.1.00776

20 Heldring N, Pike A, Andersson S, Matthews J, Cheng G, Hartman J, Tujague M, Ström A, Treuter E, Warner M and Gustafsson JA: Estrogen receptors: How do they signal and what are their targets? Physiol Rev 87: 905-931, 2007. PMID: 17615392. DOI: 10.1152 /physrev.00026.2006

21 Grilli S: Review: Tamoxifen (TAM), the dispute goes on. Ann Ist Super Sanita 42(2): 170-173, 2006. PMID: 17033137.

22 Woodcock J, Griffin JP and Behrman RE: Development of novel combination therapies. N Engl J Med 364: 985-987, 2011. PMID: 21323535. DOI: 10.1056/NEJMp1101548

23 Straetemans R, O’Brien T, Wouters L, Van Dun J, Janicot M, Bijnens L, Burzykowski1 T and Aerts M: Design and analysis of drug combination experiments. Biometrical J 47(3): 299-308, 2005. PMID: 16053254. DOI: 10.1002/bimj.200410124

24 Wagner H: Synergy research: Approaching a new generation of phytopharmaceuticals. Fitoterapia 82: 34-37, 2011. PMID: 21075177. DOI: $10.1016 /$ j.fitote.2010.11.016
25 Cridge BJ, Larsen L and Rosengren RJ: Curcumin and its derivatives in breast cancer: Current developments and potential for the treatment of drug-resistant cancers. Oncol Disc, 2013. Available at http://www.hoajonline.com/oncology/2052-6199/1/6. Last accessed on 05 December 2019.

26 Zhou D, Wang X, Yang M, Shi X, Huang W and Feng Q: Combination of low concentration of (-)-epigallocatechin gallate (EGCG) and curcumin strongly suppresses the growth of nonsmall cell lung cancer in vitro and in vivo through causing cell cycle arrest. Int J Mol Sci 14: 12023-12036, 2013. PMID: 23739680. DOI: $10.3390 /$ ijms 140612023

27 Shishodia S: Molecular mechanisms of curcumin action: Gene expression. Biofactors 39: 37-55, 2013. PMID: 22996381. DOI: 10.1002/biof.1041

28 Dzeyk J, Yadav B and Rosengren RJ: Experimental therapeutics for the treatment of triple-negative breast cancer. In: Breast Cancer - Current and Alternative Therapeutic Modalities. Gunduz E (ed.). Croatia, In Tech, 2011. Available at https://www.intechopen.com/books/breast-cancer-current-andalternative therapeutic-modalities/experimental-therapeutics-forthe-treatment-of-triple-negative-breast-cancer. Last accessed on 05 December 2019.

29 Aggarwal BB: Targeting inflammation-induced obesity and metabolic diseases by curcumin and other nutraceuticals. Annu Rev Nutr 30: 173-199, 2010. PMID: 20420526. DOI: 10.1146/annurev.nutr.012809.104755

30 Aggarwal BB, Kumar A and Bharti AC: Anticancer potential of curcumin: preclinical and clinical studies. Anticancer Res 23: 363-398, 2003. PMID: 12680238.

31 Duvoix A, Blasius R, Delhalle S, Schnekenburger M, Morceau F, Henry E, Dicato M and Diederich M: Chemopreventive and therapeutic effects of curcumin. Cancer Lett 223: 181-190, 2005. PMID: 15896452. DOI: 10.1016/j.canlet.2004.09.041

32 De Clercq E: Recent highlights in the development of new antiviral drugs. Curr Opin Microbiol 8(5): 552-560, 2005. PMID: 16125443. DOI: 10.1016/j.mib.2005.08.010

33 Ammon HP and Wahl MA: Pharmacology of Curcuma longa. Planta Med 57: 1-7, 1991. PMID: 2062949. DOI: 10.1055/s2006-960004

34 Nelson KM, Dahlin JL, Bisson J, Graham J, Pauli GF and Walters MA: The essential medicinal chemistry of curcumin. J Med Chem 60(5): 1620-1637, 2017. PMID: 28074653. DOI:10.1021/acs.jmedchem.6b00975

35 Burgos-Moron E, Calderon-Montano JM, Salvador J, Robles A and Lopez-Lazaro M: The dark side of curcumin. Int J Cancer 126: 1771-1775, 2010. PMID: 19830693. DOI: 10.1002/ijc.24967

36 Lopez-Lazaro M: Anticancer and carcinogenic properties of curcumin: Considerations for its clinical development as a cancer chemopreventive and chemotherapeutic agent. Mol Nut Food Res 52: S103-S127, 2008. PMID: 18496811. DOI:10.1002/mnfr. 200700238

37 Sen GS, Mohanty S, Hossain DM, Bhattacharyya S, Banerjee S, Chakraborty J, Saha S, Ray P, Bhattacharjee P, Mandal D, Bhattacharya A, Chattopadhyay S, Das T and Sa G: Curcumin enhances the efficacy of chemotherapy by tailoring p65 NFkBp300 cross-talk in favor of p53-p300 in breast cancer. J Biol Chem 286(49): 42232-42247, 2011. PMID: 22013068. DOI: 10.1074/jbc.M111.262295

38 Reuter S, Eifes S, Dicato M, Aggarwal BB and Diederich M: Modulation of anti-apoptotic and survival pathways by curcumin 
as a strategy to induce apoptosis in cancer cells. Biochem Pharmacol 76: 1340-1351, 2008. PMID: 18755156. DOI: 10.1016/j.bcp.2008.07.031

39 Karunagaran D, Rashmi R and Kumar TR: Induction of apoptosis by curcumin and its implications for cancer therapy. Curr. Cancer Drug Targets 5: 117-129, 2005. PMID: 15810876. DOI: $10.2174 / 1568009053202081$

40 Bhandarkar SS and Arbiser JL: Curcumin as an inhibitor of angiogenesis. Adv Exp Med Biol 595: 185-95, 2007. PMID: 17569211. DOI: $10.1007 / 978-0-387-46401-5 \_7$

41 Shehzad A and Lee YS: Review: Molecular mechanisms of curcumin action - signal transduction. Biofactors 39(1): 27-36, 2013. PMID: 23303697. DOI: 10.1002/biof.1065

42 Zhang F, Koh GY, Jeansonne DP, Hollingsworth J, Russo PS, Vicente G, Stout RW and Liu Z: A novel solubility-enhanced curcumin formulation showing stability and maintenance of anticancer activity. J Pharm Sci 100(7): 2778-2789, 2011. PMID: 21312196. DOI: $10.1002 /$ jps.22512

43 Prasad S, Tyagi AK and Aggarwal BB: Recent developments in delivery, bioavailability, absorption and metabolism of curcumin: The golden pigment from golden spice. Cancer Res Treat 46(1): 2-18, 2014. PMID: 24520218. DOI: 10.4143/crt.2014.46.1.2

44 de Moraes TA, Filha MJ, Camara CA, Silva TM, Soares BM, Bomfim IS, Pessoa C, Ximenes GC and Silva Junior VA: Synthesis and cytotoxic evaluation of a series of 2-amino-naphthoquinones against human cancer cells. Molecules 19(9): 13188-13199, 2014. PMID: 25162959. DOI: 10.3390/molecules190913188

45 Davids H, Theunissen R, Chakravorty S, Mohammed R, Frost C, Van Otterlo WAL and De Koning CB: Aminonaphthoquinones as potential anti-breast cancer agents. Afr J Pharm Pharmacol 6(45): 3102-3112, 2012. DOI: 10.5897/AJPP12.087

46 Pereira MC, Mohammed R, Van Otterlo WAL, De Koning CB and Davids H: Evaluation of the effects of aminonaphthoquinone derivatives in combination with curcumin against ER(+) breast cancer and related tumours. Anticancer Res 37: 6749-6759, 2017. PMID: 29187453. DOI: 10.21873/anticanres.12135

47 Pignatelli $\mathrm{M}$ and Stamp G: Integrins in tumour development and spread. Cancer Surv 24: 113-127, 1995. PMID: 7553657.

48 Minn AJ, Kang Y, Serganova I, Gupta GP, Giri DD, Doubrovin M, Ponomarev V, Gerald WL, Blasberg R and Massagué J: Distinct organ-specific metastatic potential of individual breast cancer cells and primary tumours. J Clin Invest 115(1): 44-55, 2005. PMID: 15630443. DOI: 10.1172/JCI22320

49 Booden MA, Ekert L, Der CJ and Trejo J: Persistent signalling by dysregulated thrombin receptor trafficking promotes breast carcinoma cell invasion. Mol Cell Biol 24: 1990-1999, 2004. PMID: 14966279. DOI: 10.1128/mcb.24.5.1990-1999.2004

50 Mathew N, Karunan T, Srinivasan L and Muthuswamy K: Synthesis and screening of substituted 1,4-naphthoquinones (NPQs) as antifilarial agents. Drug Dev Res 71: 188-196, 2010. DOI: $10.1002 / \mathrm{ddr} .20357$

51 Bhattacharyya S: 2-Chloro-3-(4-morpholino)-1,4-naphtho-quinone. Molecules 5: M160, 2000. DOI: 10.3390/M160
52 Zhao L, Wientjes MG and Au JL: Evaluation of combination chemotherapy: integration of nonlinear regression, curve shift, isobologram, and combination index analyses. Clin Cancer Res 10: 7994-8004, 2004. PMID: 15585635. DOI: 10.1158/10780432.CCR-04-1087

53 Greco WR, Bravo G and Parsons JC: The search for synergy: A critical review from a response surface perspective. Pharmacol Rev 47(2): 331-385, 1995. PMID: 7568331.

54 Chou TC and Talalay P: Quantitative analysis of dose-effect relationships: The combined effects of multiple drugs or enzyme inhibitors. Adv Enzyme Regul 22: 27-55, 1984. PMID: 6382953. DOI: 10.1016/0065-2571(84)90007-4

55 Danhof M, de Jongh J, De Lange EC, Della Pasqua O, Ploeger BA and Voskuyl RA: Mechanism-based pharmacokineticpharmacodynamic modeling: Biophase distribution, receptor theory, and dynamical systems analysis. Annu Rev Pharmacol Toxicol 47: 35-400, 2007. PMID: 17067280. DOI: 10.1146/ annurev.pharmtox.47.120505.105154

56 Berenbaum MC: Synergy, additivism and antagonism in immunosuppression: A critical review. Clin Exp Immunol 28: 118, 1977. PMID: 324671.

57 Mosmann T: Rapid colorimetric assay for cellular growth and survival: application to proliferation and cytotoxicity assays. J Immunol Methods 65(1-2): 55-63, 1983. PMID: 6606682. DOI: 10.1016/0022-1759(83)90303-4

58 Humphries M: Cell-substrate adhesion assays. Curr Protoc Cell Biol Chapter 9: Unit 9, 1998. PMID: 18228391. DOI: 10.1002/0471143030.cb0901s00

59 Boyden S: The chemotactic effect of mixtures of antibody and antigen on polymorphonuclear leucocytes. J Exp Med 115: 453466, 1962. PMID: 13872176. DOI: 10.1084/jem.115.3.453

60 Sieuwerts AM, Klijn JGM and Foekens JA: Assessment of the invasive potential of human gynecological tumor cell lines with the in vitro Boyden chamber assay: Influences of the ability of cells to migrate through the filter membrane Clin Exp Metastasis 15: 53-62, 1997. PMID: 9009106. DOI: 10.1023/a:10 18436407280

61 Subramani T, Yeap SK, Ho WY, Ho CL, Osman CP, Ismail NH, Rahman N and Alitheen NB: Nordamnacanthal potentiates the cytotoxic effects of tamoxifen in human breast cancer cells. Oncol Lett 9(1): 335-340, 2015. PMID: 25435988. DOI: 10.3892/ol.2014.2697

62 Darakhshan S, Bidmeshkipour A, Mansouri K, Saeid HM and Ghanbari A: The effects of tamoxifen in combination with tranilast on CXCL12-CXCR4 axis and invasion in breast cancer cell lines. Iran J Pharm Res 13(2): 683-693, 2014. PMID: 25237365 .

Received November 27, 2019

Revised December 9, 2019

Accepted December 12, 2019 